European journal of American studies

Spring 2017: Special Issue - Eleanor Roosevelt and Diplomacy in the Public Interest

\title{
Conclusion: Eleanor Roosevelt and Her Transatlantic Quest for Equality and Freedom
}

Dario Fazzi

\section{OpenEdition}

\section{Journals}

Electronic version

URL: https://journals.openedition.org/ejas/11958

DOI: $10.4000 /$ ejas. 11958

ISSN: 1991-9336

Publisher

European Association for American Studies

Electronic reference

Dario Fazzi, "Conclusion: Eleanor Roosevelt and Her Transatlantic Quest for Equality and Freedom", European journal of American studies [Online], 12-1 | 2017, document 9, Online since 14 March 2017. connection on 08 July 2021. URL: http://journals.openedition.org/ejas/11958 ; DOI: https://doi.org/ 10.4000/ejas. 11958

This text was automatically generated on 8 July 2021.

Creative Commons License 


\title{
Conclusion: Eleanor Roosevelt and Her Transatlantic Quest for Equality and Freedom
}

\author{
Dario Fazzi
}

1 The overt aim of this collection has been to provide a preliminary account of Eleanor Roosevelt's multifaceted attempts to reshape the image of the United States abroad, her foreign entanglements, and, in particular, her formal and informal interactions with Europe. In dealing with such an ambitious goal, all the contributors have pointed out that one of Mrs. Roosevelt's main (public) diplomacy efforts was to translate the old demands of a certain American liberalism - i.e. internationalism, multilateralism, fair cooperation among the nations, and so on - into an effective and mutually enriching transnational, namely transatlantic, exchange.

2 To strengthen the validity of such an argument, the contributors have been following the way paved by Mary Nolan's seminal volume on the Transatlantic Century. In her study, Nolan has not only demonstrated that the U.S. and Europe have constantly kept influencing each other in much more interdependent ways than it is usually argued, but she has also convincingly argued that, along with a steady flow of goods and capital across the Atlantic, a constant intercultural exchange has favored the strengthening of the transatlantic ties. This paradigm, which David Armitage and, more recently, Maurizio Vaudagna have defined as "circum-Atlantic" in the attempt to stress the relevance of "the larger relational networks that define the circulation of cultures, ideas, goods, and people" from Europe to the U.S. and vice versa, openly challenges the idea that U.S. hegemony has descended upon Europe in a unidirectional way, a concept that is very much entrenched in most of the literature on the so-called U.S. empire. ${ }^{i}$

3 Taken together these interpretations have had the merit to bring to the fore the strength of those varied personal interests and intercultural connections that have bound the two shores of the Atlantic inextricably together.i ${ }^{\text {ii }}$ The essays presented in this collection go along these transnational lines of inquiry and try to further substantiate such an unconventional approach by looking at the exemplary story of 
Eleanor Roosevelt. In doing so, the contributors have also implicitly accepted Joseph Rezek's methodological invitation to refer to the transatlantic relations as a challenging multiplicity, and their analyses have therefore adopted a theoretical framework that has preferred to look at the transatlantic relations not only through the traditional lenses represented by grand strategies, military planning, economic exchanges, or state diplomacy, but also, and most prominently, through the paradigms of informal diplomacy, cross-cultural exchanges, ideology, popular culture, and personal encounters. iii

4 This collection represents therefore an attempt to search for the footprints that Eleanor Roosevelt has left in the long path traced by the Euro-American relations throughout the twentieth century. The major outcomes of this complex inquiry rest in the rendering of Mrs. Roosevelt's transatlantic effort mostly as a personal commitment, a relentless attempt to foster the ideals of equality and freedom across the Atlantic in order to preserve and support people's primary role - and basic rights - in the international arena. Eleanor Roosevelt, indeed, fiercely believed that, to use FDR's second inaugural address words, the main task for the governments should be to "promote the general welfare and to secure the blessing of liberty." Both of the Roosevelts realized fully that the most challenging part of this job was not "to add more to the abundance of those who have much;" rather, it was to "provide enough for those who have too little." ${ }^{\text {iv } M r s . ~ R o o s e v e l t ~ w a s ~ a ~ s p l e n d i d ~ i n t e r p r e t e r ~ o f ~ t h i s ~ g e n u i n e l y ~}$ liberal interest in paying careful attention to common people's individual and collective needs, and she worked hard to improve their actual standards of living. ${ }^{.}$She kept advocating for the oppressed and the poorest not only as a social worker but also as a first lady, as a diplomat, a public intellectual, a communicator, a writer, and a mass educator.

5 Dario Fazzi's contribution to this collection and Melissa Cooper's one have tried to delve deeper into these dynamics, so as to explain the many ways in which, throughout her life, Eleanor Roosevelt has tried to advance the cause of equality and social justice. Her social activism has oftentimes reverberated in her own understanding of the Atlantic space, which she mostly considered as a space of opportunity for people's empowerment and development. On the other hand, Raffaella Baritono's analysis and Camelia Lenart's contribution have vividly shown how such a major focus on social justice and reform did not only translate into staunch internationalism, but it also resulted into an attempt to deepen both the meaning and the purpose of the transatlantic exchange. Eleanor Roosevelt played a major role in qualifying the Atlantic space in moral terms, by assigning people in Europe and in the U.S. - the "below" level as Baritono puts it - the daunting task to preserve international stability and peace.

6 The other concept that Eleanor Roosevelt presented as a crucial building block for a new and more solid transatlantic exchange was freedom. Quite famously, her views on freedom found their synthesis in the Universal Declaration of Human Rights. ${ }^{\text {vi }}$ Having chaired the U.N. committee that had drafted that document, Mrs. Roosevelt had supervised all of the debates over the philosophical definition of human rights and, more importantly, had tried to negotiate a common, universal frame of reference for them. ${ }^{\text {vii }}$ But she stressed in many occasions the importance of a quintessentially western principle, the "respect for, and observance of, human rights and fundamental freedoms for all without distinction as to race, sex, language, or religion." That was the 
pillar upon which to establish new forms of transnational cooperation, across the Atlantic and beyond it, and build a new world order based on human rights. viii

7 As Babs Boter has emphasized in her essay, intercultural understanding played a crucial role in Eleanor Roosevelt's attempt to shape the transatlantic relations from below. According to Mrs. Roosevelt, indeed, this process had to convince people in Europe and in the U.S. that they shared a common interest, which was specifically the building of "a different and better future," based on mutual respect among the people of the world. ${ }^{\text {ix }}$ But, what made Eleanor Roosevelt's appeal perhaps more authoritative was, as Anya Luscombe and Sara Polak have rightly argued, her unmatched ability to master a wide range of techniques of communication, mobilization, and consensusbuilding. ${ }^{\mathrm{x}}$ She conveyed her messages of freedom and equality through an impressive number of radio and TV addressees, public lectures, and widely syndicated columns, thus constantly reminding, especially young people in both Europe and the U.S., that they were the ultimate responsible for the successful establishment of world stability and peace. With her evocative rhetoric, she called for a new world order centered on citizens' happiness and on their inalienable right to hope.

8 Eleanor Roosevelt firmly believed that, given their high standards of education and living, European and American people shared a compelling moral obligation to foster freedom and equality worldwide, two ideals that in Eleanor Roosevelt's vocabulary were oftentimes used interchangeably with democracy. In transatlantic terms, thus, Eleanor Roosevelt's most important achievement can be considered her unremitting effort to raise citizens' full awareness of their own rights and duties. In doing so, she contributed to a large extent to laying the foundations for the transnational campaign in defense of western democracy - or the western idea of democracy - that has characterized most of the second half of the twentieth century. Mrs. Roosevelt's legacy is therefore instrumental to ferret out the subsistence of a set of shared principles, values, and interests still affecting, for better or for worse, the transatlantic space and exchange.

\section{NOTES}

i. See Maurizio Vaudagna, "Introduction," in Maurizio Vaudagna (ed.), Modern EuropeanAmerican Relations in the Transatlantic Space: Recent Trends in History Writings (Turin: Otto, 8-9).

ii. See Mary Nolan, The Transatlantic Century: Europe and the United States, 1890-2010 (New York: Cambridge University Press, 2012).

iii. See Joseph Rezek, "What We Need from Transatlantic Studies," in American Literary History, vol. 26, no. 4 (Winter 2014), 791-803.

iv. See Franklin D. Roosevelt, Second Inaugural Address, January 20, 1937, in Documentary History of the Franklin D. Roosevelt Presidency, vol. 50, FDR Selected Speeches, Document 18 (Bethesda: UPA, 2011), 166.

v. See Dan Eshet, Fundamental Freedoms. Eleanor Roosevelt and the Universal Declaration of Human Rights (Brookline: Facing History and Ourselves National Foundation, 2010). 
vi. The original version of the Declaration is available online, at the U.N. web page: http:// www.un.org/en/documents/udhr/index.shtml.

vii. A complex and detailed account of the Declaration and its enormous impact is given by Mary Ann Glendon, A World Made New. Eleanor Roosevelt and the Universal Declaration of Human Rights (New York: Random House, 2001).

viii. Jason Berger, A New Deal for the World (New York: Columbia University Press, 1981), 67-72 and Tamara K. Hareven, Eleanor Roosevelt. An American Conscience (New York: Quadrangle Books, 1968) 235-242. See also Allida M. Black (ed.), The Eleanor Roosevelt Papers: Vol. 1. The Human Rights Years, 1945-1948 (New York: Thomson Gale, 2007), 298.

ix. See Eleanor Roosevelt, My Day, January 28, 1942, in http://www.gwu.edu/ erpapers/myday/. x. See Maurine Hoffman Beasley, Eleanor Roosevelt. Transformative First Lady, (Lawrence: University Press of Kansas, 2010), 77.

\section{AUTHOR}

\section{DARIO FAZZI}

Roosevelt Study Center 